\title{
THE EXISTENCE OF FOREIGN TRADE BALANCE CONVERGENCE IN EU MEMBER AND CANDIDATE COUNTRIES: AN EMPIRICAL ANALYSIS
}

\section{Oğuzhan ÖZÇELIKK ${ }^{1}$ Hasan BARDAKÇI ${ }^{2}$}

\begin{abstract}
In this study, the presence of convergence among the EU member and candidate countries in terms of the foreign trade balance was analyzed with second-generation panel data analysis methods, operating under cross-sectional dependence, by using data from the 2000-2019 period. In the research, firstly the existence of cross-sectional dependence among the countries was analyzed and it was found that there was cross-sectional dependence among the countries included in the panel. Finally, the convergence of EU candidate countries to the EU13's foreign trade balance average was tested by CADF and HK methods, and according to the CADF tests, the EU candidate countries that were unable to converge to the EU15 countries were also not able to converge to the EU13 countries.
\end{abstract}

Keywords: Convergence, Foreign Trade Balance, Cross-Sectional Dependence, Panel Unit Root Tests.

\section{AB ÜYESİ VE ADAYI ÜLKELERDE DIŞ TİCARET DENGESİ SÜRDÜRÜLEBİLIRLİĞİ VE YAKINSAMASININ VARLIĞI: AMPÍRİK BİR ANALIZ}

ÖZ

Bu çalışmada AB üyesi ve AB’ye aday ülkeler arasında dış ticaret dengesi yönünden bir yakınsamanın varlığı, 2000-2019 dönemi verileri kullanılarak, yatay kesit bağımlılı̆̆ı altında çalışan ikinci nesil panel veri analizi yöntemleriyle incelenmiştir. Çalışmada öncelikle analize dahil edilen ülkeler arasında yatay kesit bağımlılığının varlığı testleri yapılmış ve panele dahil edilen ülkeler arasında yatay kesit bağımlılığının var olduğu tespit edilmiştir. Son olarak; AB adayı ülkelerin AB13'ün dış ticaret dengesi ortalamasına yakınsamasının varlığı CADF ve HK yöntemleriyle test edilmiş ve CADF'e göre AB15 ülkelerine yakınsayamadıkları görülen $A B$ adayı ülkelerin, AB13 ülkelerine de yakınsayamadıkları görülmüştür.

Anahtar Kelimeler: Yakınsama, Dış Ticaret Dengesi, Yatay Kesit Bağımlılığı, Panel Birim Kök Testi

${ }^{1}$ Öğr. Gör. Dr., Kırklareli Üniversitesi, oguzhanozcelik@klu.edu.tr, ORCID:0000-0001-6666-8976

2 Dr. Öğretim Üyesi, Harran Üniversitesi, hasanbardakci@ harran.edu.tr, ORCID:0000-0002-6181-3115

Atıf/Citation: Özçelik, O. \& Bardakçı, H. (2021). The Existence of Foreign Trade Balance Convergence In Eu Member and Candidate Countries: An Empirical Analysis, Kırklareli Üniversitesi Sosyal Bilimler Meslek Yüksekokulu Dergisi, 2(1), 57-80. 


\section{INTRODUCTION}

The viewpoint that suggests free foreign trade will increase the total amount of production and the welfare of all participating countries by increasing the division of labor and specialization among countries has been widely accepted since Smith (1776). Through foreign trade, the production scale of firms will grow, and they will be able to reduce their costs by taking advantage of scale economies and increase their competitiveness and profits for foreign trade. Through foreign trade, which would enable efficient use of scarce resources in the economy and increase in productivity, countries would get the opportunity to both reduce production costs and use new production technologies by purchasing intermediate and capital goods from other countries. The competitive pressure that foreign trade would create on domestic companies will force them to allocate more resources for Research and Development (R\&D) and innovation; and thus, it would increase their productivity and have a positive effect on their production quality.

In addition to these beneficial effects, free foreign trade may cause domestic companies that cannot compete with international companies in domestic and foreign markets to be crowding-out from the sector and may cause a decrease in domestic production (Samue, 2019). For example, China's inclusion into the World Trade Organization in December 2001 enabled it to enter the world markets rapidly and to gain a good position in these markets with the cheap goods it produces with its cheap labor. In this process, $95 \%$ of the Turkish toy companies, which could not manage to compete with the Chinese toy industry, stopped their production and started selling the toys imported from China in the domestic market (ATO, 2003). Although such a situation seems to be in favor of companies in the short term, it may cause the weakening of the country's production capability in the long term and deindustrialization in related markets (Rowthorn and Ramaswamy, 1997).

The reflection of this process on the country's economy revealed itself as an increase in the foreign trade deficit and current account deficit. The excessive increases in current account deficit brings the risk for countries to fall into an economic crisis (Dornbusch and Fischer, 1990; Freund, 2000; Labonte, 2010). One of the important reasons for the 1994 and 2001 economic crises experienced by Turkey was the high current account deficits experienced at that time. The European Union directs and supports both its Member States and candidate countries in order to reduce their current account deficits and trade balance deficits. There are EU funds 
allocated for a solution, and grants are provided to countries through these funds, provided that they implement the proposed programs (European Commission, 2015).

Particularly underdeveloped and developing countries may suffer from the negative effects of the international free foreign trade. Because these countries cannot produce and export high-tech and capital-intensive products like the developed countries, and thus cannot receive a high amount of foreign exchange income. The underdeveloped/developing countries that generally produce and export low-tech or labor-intensive products may face to the foreign trade deficit problem by obtained less foreign exchange income. This trade deficit increases countries' need for foreign funding and causes an increase in their fragility to external economic shocks (Hawkins and Turner, 2008).

Within this context, the existence of a convergence for foreign trade balances among the European Union (EU) Member Countries and EU candidate countries was analyzed by using new generation panel data analysis methods with annual data for the 2000-2019 period. In addition to the 36-country panel in general, the analyzes were repeated for the EU28 3 countries, EU15 countries, 13 countries that joined the EU later, and 8 EU candidate countries. It was also tested whether the foreign trade balances of these countries converge to the group averages of the EU15 and EU13. In the second part of the study, the theoretical framework of convergence was discussed; in the third part, the foreign trade balances of the countries included in the analysis were evaluated with graphics and tables; in the fourth part, the results of the literature review on the subject were shared; and in the fifth part, empirical analyses were performed. The study was completed with evaluation and policy recommendations. It is believed that this study will contribute to the literature and policy makers as well as Turkish economy in which the current account deficit began to rise again.

\section{Theoretical Framework of Convergence}

Convergence, in its general meaning, refers to the tendency to approach a single point, to become increasingly closer/similar, or to become identical in the process. As an economic term, it refers to the poor countries growing faster and catching up with or getting closer to the rich countries. This concept, which is also referred to as Catch-Up Theory in the literature, is mostly used to express those countries will be more alike in terms of per capita income (Burkett and Hart-Landsberg, 2003).

\footnotetext{
${ }^{3}$ In the data period of the study, for the UK was an EU member, the UK also took part in the analyzes as an EU Member country in this study.
} 
In the Neoclassical Economic Growth Model developed by the Solow (1956) and Swan (1956); in accordance with the principle of diminishing marginal productivity of capital, it was stated that the growth rate of developed countries will decrease over time, contrarily underdeveloped and developing countries will grow faster and converge to developed countries over time (Varblane and Vahter, 2005). In short converge the concept of can be defined as economies becoming similar to each other in terms of the growth rate, the level of per capita income, or on another scale (Atalay, 2007). The best examples of economic convergence are countries such as Japan, Germany, South Korea, and China. Japan and Germany, which suffered from great losses due to the Second World War, grew faster than other countries and took their place in the category of developed countries; South Korea and China are also on their way to reach the level of developed countries.

Lucas (2000) stated that the most important incident of the 21st century would be convergence, and the underdeveloped regions will eventually catch up with Western countries. The author suggested the following as reasons for this thought: (i)The factors that restrain economic growth in underdeveloped countries will be overcome with the correct policies and institutions, (ii) Capital flows from developed countries to developing countries will be accelerated as a result of the globalization; thus, domestic saving gap in less developed countries can be prevented from restricting the growth and (iii) Total factor productivity will increase as a result of the developments in education and health in developing countries.

Scientists have used different methods to test the existence of convergence among countries, regions and even cities. Among these, the absolute and conditional Beta Convergence Approach developed by Barro and Sala-i-Martin (1990) and the Sigma Convergence Approach developed by Sala-i-Martin (1996) are highly important. These approaches test the convergence of all countries to the most developed country in the group. The Club Convergence Approach developed by Baumol (1986), Durlauf and Johnson (1995) and Galor (1996) suggest that countries can converge to a special equilibrium. With this idea, economists have developed testing methods to test whether countries converge to a leading country (Saracoglu and Dogan, 2005; Gogul and Korap, 2014), the average of a developed country group, or the group's own average (Saracoglu and Dogan, 2005; 2013; Gogul and Korap, 2014). Moreover, this issue is not only valid for income convergence anymore, but it is rather being adapted to many areas today (Webwer and Beck, 2005; Lopez and Papell, 2012; Arestis et al., 2014; Karanasos, et al., 2016). 
In order to test the existence of convergence to the leading country for a $X$ variable; data of the leader country ${ }^{4}\left(X_{t}^{l}\right)$ is subtracted from the data of each country $\left(X_{i t}\right)$. Equation 1 is used in this process:

$$
X_{i t}^{*}=X_{i t}-X_{t}^{l}
$$

Then, the stationarity of the new series $\left(X_{i t}^{*}\right)$ is tested, and if the series is stationary, it is considered that the countries converge to the leading country (Gogul and Korap, 2014). Similarly, in order to test the existence of convergence to the average of the country group $\left(\bar{X}_{t}\right)$ for a variable $X$, the average of the group $\left(\bar{X}_{t}\right)$ is subtracted from the data of each country $\left(X_{i t}\right)$. Equation 2 is used in this process:

$$
\overline{\bar{X}}_{i t}=X_{i t}-\bar{X}_{t}
$$

Again, the stationarity of the new series $\left(\overline{\bar{X}}_{i t}\right)$ is tested, and if the series is stationary, it is considered that the countries converge to the leading country (Saracoglu and Dogan, 2005).

\section{Foreign Trade Balance of Countries}

The balance of trade $(B T)$ is the difference between exports $(X)$ and imports $(M)$, which is also called net exports $(N X)$ in the literature. Foreign trade balance in a period $(t)$ can be calculated with the help of Equation (3).

$$
B T_{t}=X_{t}-M_{t}
$$

A country experiences a foreign trade deficit when the BT has negative values, and a foreign trade surplus when it has positive values. Evaluating countries based solely on BT values may be misleading in some cases. Because, in negative BT situations, the refinancing options for debt and the sustainability of this deficit are also of great importance as much as the amount of deficit. For example, Turkey's BT in 2019 was -29.5 Billion Dollars (World Bank, 2021a, 2021b). This value was high for Turkey; thus, it was a too-high value in terms of sustainability of this deficit, and may be considered as a problem source. In the same period, the USA's BT was -924 Billion Dollars in 2019 (World Bank, 2021a, 2021b), yet it was insignificant since the USA did not have any problems in sustainability of this deficit. At this point, the factor that facilitates making a decision is the share of foreign trade deficit in national income (Ozdamar, 2015, pp. 634). This value can be referred to as BTGDP based on the

\footnotetext{
${ }^{4} l$; represents the leader country
} 
definition of Balance of Trade in Gross Domestic Product and can be calculated with the Equation 4.

$$
\operatorname{BTGDP}_{t}=\frac{\left(X_{t}-M_{t}\right)}{G D P_{t}} * 100
$$

According to the pioneering Maastricht Criteria adopted by the European Union in 1991, the following conditions have been accepted as a prerequisite for a member country to also can be member of monetary and economic union:

i. Price stability,

ii. Sound public finances, to ensure they are sustainable,

iii. Exchange-rate stability, to demonstrate that a Member State can manage its economy without recourse to excessive currency fluctuations

iv. Long-term interest rates, to assess the durability of the convergence (European Commission, 2021).

This reveals the need for convergence between the Member States and candidate countries on the basis of basic macroeconomic variables. Foreign trade data of the EU Member States and candidate countries evaluated in this study are included in Table 1.

Table 1: Foreign Trade Data of the EU Member States and Candidate Countries

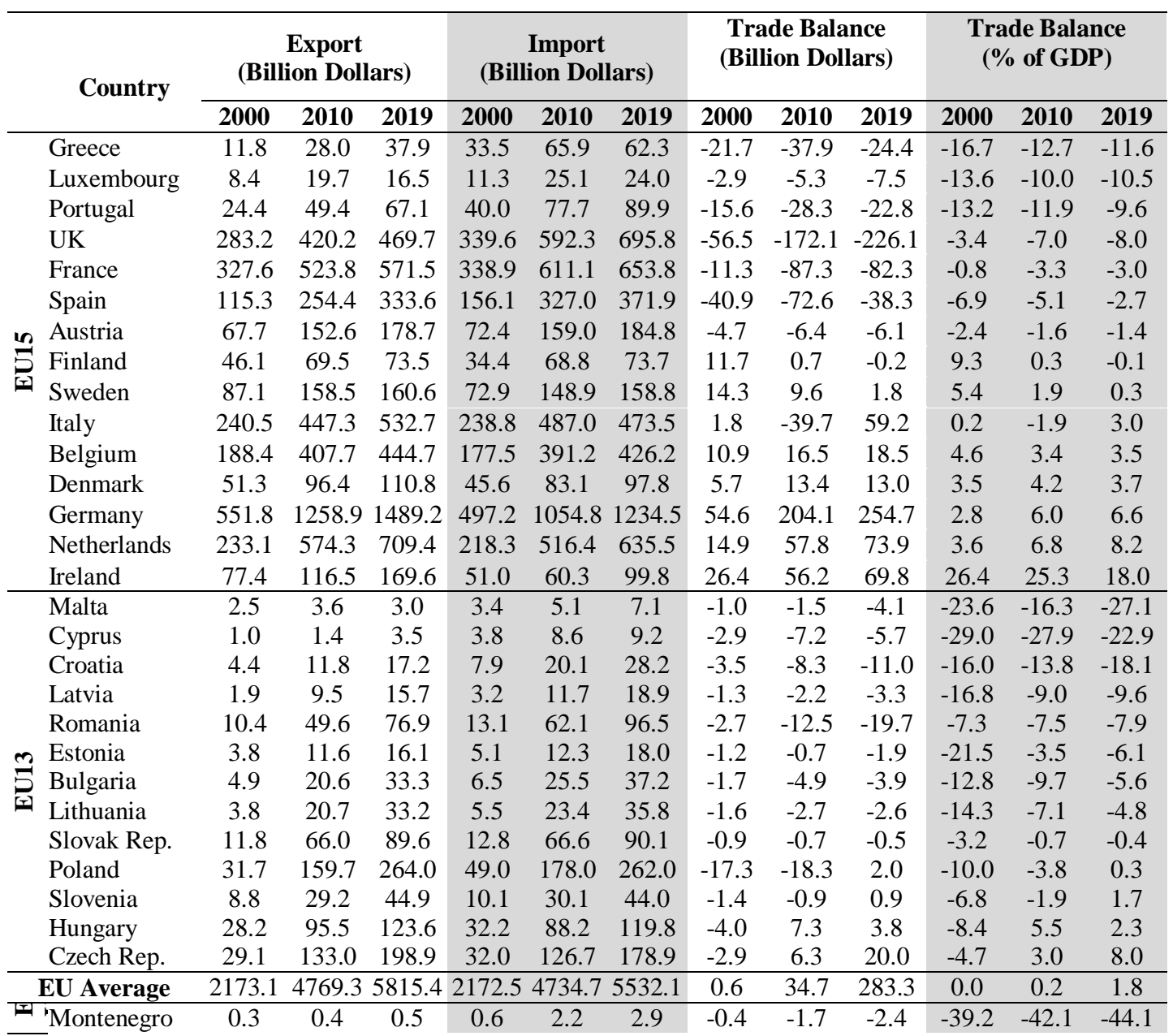




\begin{tabular}{cccccccccccccc}
\hline - Bosnia\&Herz. & 1.1 & 4.8 & 6.6 & 3.1 & 9.2 & 11.2 & -2.0 & -4.4 & -4.6 & -37.0 & -25.7 & -22.7 \\
Kosovo & 0.8 & 2.0 & 2.0 & 5.6 & 12.3 & 19.7 & -0.3 & -0.2 & -0.2 & -26.2 & -17.7 & -22.2 \\
Albania & 0.3 & 1.5 & 2.7 & 1.1 & 4.4 & 5.9 & -0.8 & -2.9 & -3.2 & -23.8 & -24.0 & -20.8 \\
N. Macedonia & 1.3 & 3.4 & 7.2 & 2.1 & 5.5 & 9.5 & -0.8 & -2.1 & -2.3 & -20.4 & -22.6 & -18.2 \\
Serbia & 0.4 & 9.8 & 19.6 & 1.2 & 16.7 & 26.7 & -0.7 & -6.9 & -7.1 & -10.8 & -16.6 & -13.8 \\
Iceland & 1.9 & 4.6 & 5.2 & 2.6 & 3.9 & 6.6 & -0.7 & 0.7 & -1.3 & -7.6 & 5.0 & -5.6 \\
$\quad$ Turkey & 27.8 & 113.9 & 180.8 & 54.5 & 185.5 & 210.3 & -26.7 & -71.7 & -29.5 & -9.7 & -9.2 & -3.9 \\
\hline
\end{tabular}
(\% of GDP) data of 2019.

According to the data in Table 1, as of 2019, the EU15 country with the highest ratio of foreign trade deficit to national income was Greece with $11.6 \%$, followed by Luxembourg with $10.5 \%$ and Portugal with $9.6 \%$. Among the EU15 countries, 7 of them had foreign trade surplus in 2019, and Ireland ranks first with $18 \%$.

It can be seen that the 13 countries that joined the EU later are generally the countries with foreign trade deficit, and Malta ranks first among them with $27.1 \%$. It was followed by Cyprus with $22.9 \%$ and Croatia, the last member, with $18.1 \%$. It can also be seen that only 4 of the EU13 countries had foreign trade surplus, and the Czech Republic ranks first with $8 \%$.

According to the general average of 28 EU countries, as of 2019, it can be seen that there was a $1.8 \%$ foreign trade surplus, and this surplus was realized with countries such as Germany, the Netherlands and Ireland, which are in the EU15 group. It can be seen that 9 of the 13 countries that joined the EU later had foreign trade deficit in 2019, and the other 4 countries had foreign trade deficits in the years before. Two interpretations may be inferred based on these data: (i) The countries that joined the EU later became a market for the EU15 countries; and (ii) EU13 countries are a burden on EU15 countries.

According to the data of $8 \mathrm{EU}$ candidate countries, it can be seen that all of these countries have foreign trade deficit. It can be seen that Montenegro ranks first with $44.1 \%$, followed by Bosnia and Herzegovina with 22.7\%, and Kosovo with 20.8\%. Turkey ranks first in this group of countries with a nominal foreign trade deficit of $\$ 29.5$ billion. However, considering the share of this deficit in GDP, it can be seen that Turkey had the best position with $3.9 \%$. Considering these data of EU candidate countries; it can be stated that the participation of these countries to the EU will bring extra burdens on the EU. One important conclusion here are that there are important differences between ranking countries according to their nominal foreign trade deficit and ranking them according to the share of this deficit in GDP, and that nominal values can be misleading.

Figure 1 is prepared to analyze by visual the existence of convergence among the averages by examining the average of the shares of the foreign trade deficits of the country groups in the GDP. 
Figure 1: Average of Country Group Shares of Foreign Trade Deficits in GDP

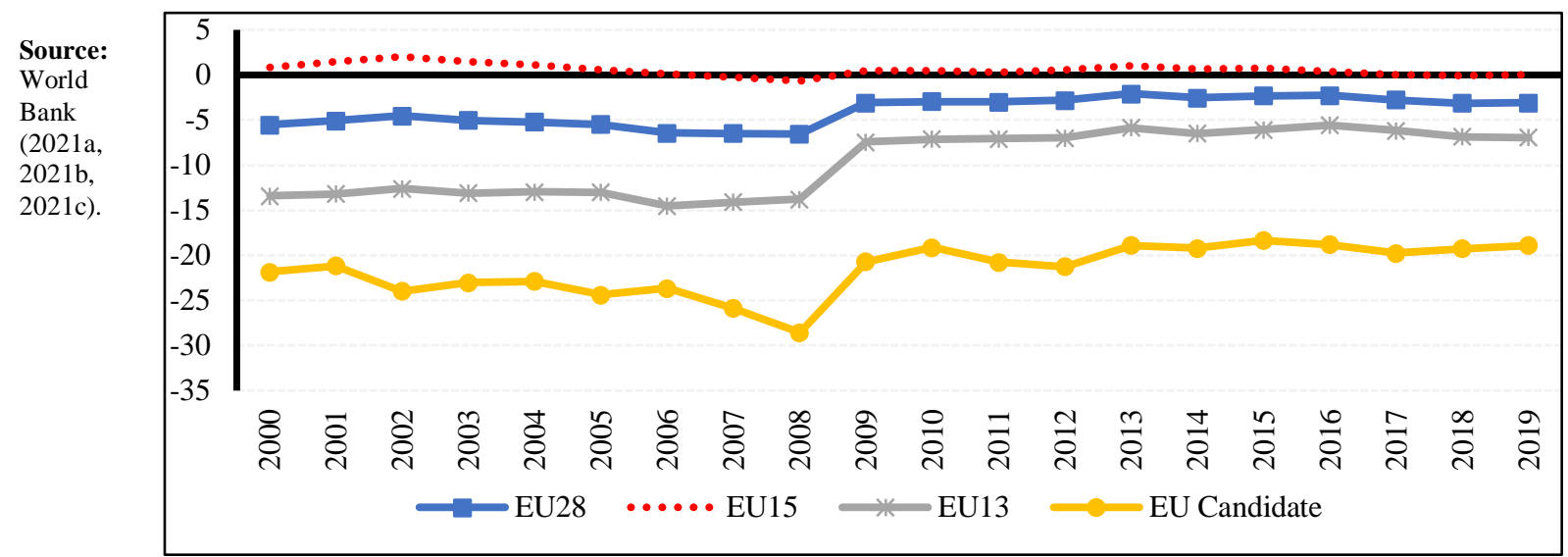

According to Figure 1, the countries that have the best position in terms of foreign trade balance are the EU15 countries. The EU28 average tends to converge to the EU15 average. On the other hand, the EU13 countries tend to converge to the EU28 countries. The countries with the worst performance in this figure are EU candidate countries. It is noteworthy that this group of countries also the states that are most affected by the 2008 global economic crisis. Therefore, according to this figure, it seems unlikely that the EU candidate countries will converge to the EU15 or EU28 in the near future.

\section{Literature Review}

According to our literature review; national income convergence has been a subject to many studies; the convergence of inflation and carbon dioxide $\left(\mathrm{CO}_{2}\right)$ emissions has been a subject to studies, albeit a little; but it has been observed that the existence of convergence among countries in terms of foreign trade balance has not been a subject to any study at all. Therefore, in this part of the study, a summary of the studies testing the existence of convergence in different subjects with unit root tests, which is the research method of this study as well, is presented in chronological order.

Strazicich, Lee and Day (2004) tested the existence of national income convergence among OECD countries with structural break unit root tests they applied to the per capita income data of these countries for the period of 1870-1994, and they found that there was an income convergence among 15 countries. Saracoglu and Dogan (2005) used quarterly data of 29 countries for the period of 1985-2004 to analyze whether the European Union (EU) member countries and candidate countries converged to France in terms of per capita income. The authors created a new panel data set by subtracting the GDPPCs of 28 countries from France's GDPPC, as they consider France as the leading country. They applied Fisher ADF, Fisher PP and IPS panel unit root tests. As the new series resulted as stationary in the analysis, $28 \mathrm{EU}$ 
member countries and EU candidate countries were determined to be converged to France in terms of GDPPC. The authors repeated the analyzes for the EU candidate countries and found that the convergence was not valid for the candidate countries. Pesaran (2007) examined the existence of convergence for real per capita income corrected for purchasing power parity of 101 countries for the period of 1950-2000 in terms of the stationarity of the series with the horizontal cross-sections pairwise and found that there was no income convergence among these countries.

Lopez and Papell (2012) tested the existence of inflation convergence within the Euro Zone, by using data from 12 countries for the period of 1979:M01-2010:M04 and by using SURADF method; it was found that there was a robust and continuous convergence on inflation among these countries. The researchers, who stated that this effect continued after 2008, also stated that the most important cause of the increased inflation in Euro Zone was Greece. Yilanci and Eris (2013) examined the validity of the Purchasing Power Parity Hypothesis for African countries by using multiple soft transition Fourier unit root test for data of 33 African countries for different periods and found that the real exchange rate series was stationary in 20 countries, and decided that the Purchasing Power Parity Hypothesis was valid among these countries. Arestis et al. (2014) analyzed the existence of inflation convergence among OECD countries with the CADF unit root test by using data for the period of 1990:Q1-2011:Q4 for countries with and without inflation targeting regime, and found that there was inflation convergence among all OECD countries, as the inflation series for country groups were found to be stationary (according to CIPS statistics), and found that this situation was independent from the implementation of inflation targeting. Gogul and Korap (2014) examined the existence of convergence in terms of GDPPC for 26 OECD countries with the Panel ADF, Panel PP, LLC and IPS panel unit root tests, by using data from the period of 1970-2012. The authors who had a new panel dataset by subtracting the GDPPC value of each country from GDPPC value of the USA, and as a result of analysis this series found to be stationary, they determined that OECD countries in convergence to the GDPPC of the USA, the leading country. Gencoglu, Kuskaya and Buyuknalbant (2020) analyzed the sustainability of health expenditures for 21 selected OECD countries by using CADF, Hadri and Kurozumi and SURADF tests using 1975-2017 data, and concluded that health spending in these countries was sustainable because the series found to be stationary

\section{Empirical Analysis}




\subsection{Data Set}

In this study, in order to test the existence of convergence in terms of foreign trade balance among EU member and candidate countries; by using the foreign trade (merchandise export (World Bank, 2021a), merchandise import (World Bank, 2021b)) and GDP (World Bank, 2021e) data of the countries in Table 1 for the period of 2000-2019, the share of foreign trade balance within GDP calculated by us with Equation (4) was used. 15 countries among those countries listed in Table 1 are the main EU Member States, which are also referred as developed countries. The EU13 countries are the countries that joined the EU in 2004 (Hungary, Poland, Czech Republic, Slovakia, Slovenia, Latvia, Lithuania, Estonia, Malta, Cyprus), in 2007 (Romania, Bulgaria), and in 2013 (Croatia). The 6 of 8 countries that are candidate for participating (Turkey, Iceland, Northern Macedonia, Montenegro, Serbia and Albania) are official candidate while the other 2 (Bosnia and Herzegovina and Kosovo) are considered unofficially candidate of EU membership. The selection of the data period is based on the Agenda 2000 summit, which was accepted during the EU's enlargement. Because, at this summit, the basic practices that EU candidate countries must do were decided. The end point of the data period was determined as the last period of which data can be accessed.

\subsection{Methodology}

In this study, the average $\overline{B T G D P}$ of the BTGDP data of the countries for each group was obtained with Equation 4; as a result of this operation, their series were obtained; and then this value was subtracted from the BTGDP values of the countries, and thus BTGDP* series were obtained. The equation for this operation:

$$
B T G D P_{i t}^{*}=\mathrm{BTGDP}_{i t}-\overline{B T G D P}_{t}
$$

Then, the stationarity of the $B T G D P_{i t}^{*}$ series was tested, and so on the existence of convergence among countries in terms of foreign trade deficit was analyzed econometrically. These analyzes were performed for the 36-country panel as well as for the EU28, EU15, EU13, and the 8 EU candidate countries.

Before testing the stationarity of the series, $L M, L M_{S}, C D$ and $L M_{B C}$ tests were conducted to test the existence of cross-sectional dependence among these countries. Then, CADF and CIPS tests developed by Pesaran (2007) and the panel unit root tests of Hadri and Kurozumi (2012) were used in order to test the stationarity of the series. Among these tests, CADF can both provide individual unit root test results and produce the general results of the panel with the CIPS statistic developed by Pesaran (2007). Hadri and Kurozumi's (2012) panel 
unit root test hypothesis is the opposite of the CADF (and CIPS) test; in a sense, these two tests crosscheck each other. In addition, Fisher ADF and Fisher PP tests developed by Maddala and Wu (1999), LLC test developed by Levin, Lin and Chu (2002) and IPS panel unit root tests developed by Im, Pesaran and Shin (2003) were performed for robustness check.

\subsubsection{Cross Sectional Dependence Test}

Cross sectional dependence refers to the effect of an economic or political shock on a country affecting other members of the group (Baltagi and Pesaran, 2007). It is of great importance to test the existence of cross-sectional dependence among the countries of the panel. If there is such a dependency, the second-generation panel data analysis methods that take this situation into account should be used. The first study to test cross sectional dependence was carried out by Breusch and Pagan (1980), and followed by Pesaran (2004) and Baltagi, Feng and Kao (2012).

Breusch and Pagan's (1980) study based on a panel data analysis model as in Equation (6) to develop the LM test:

$$
y_{i t}=\alpha_{i}+\beta_{i} x_{i t}^{\prime}+u_{i t}
$$

Here $y_{i t}$; represents the dependent variable, $\alpha_{i}$; represents the constant term, $x_{i t}^{\prime}$; represents the independent variables vector, $\beta_{i}$; represents the slope coefficient, and $u_{i t}$; represents the series of error terms with the white noise process. Equation (7) will be obtained if the error terms series is rewrite according to the $A R(m)$ process:

$$
u_{i t}=\rho_{1} u_{i t-1}+\rho_{2} u_{i t-2}+\cdots+\rho_{m} u_{i t-m}
$$

Here, the correlation coefficient is calculated with Equation (8):

$$
\hat{\rho}_{i j}=\frac{\sum_{t \in(i, j)}^{T_{k j}} \hat{u}_{i t} \hat{u}_{j t}}{\left(\sum_{t \in(i, j)}^{T_{k j}} \hat{u}_{i t}^{2}\right)^{1 / 2}\left(\sum_{t \in(i, j)}^{T_{k j}} \hat{u}_{j t}^{2}\right)^{1 / 2}}
$$

Then, Lagrange Multiplier (LM) test statistic is obtained with Equation (9):

$$
L M=\sum_{i=1}^{N-1} \sum_{j=i+1}^{N} T_{i} \hat{\rho}_{i j}^{2}
$$

Here $T$; refers to time dimension of the panel, and $N$; refers to the cross-section dimension. The null hypothesis of this test is $" \operatorname{Corr}\left(u_{i t}, u_{j t}\right)=0, i \neq j$, that is, there is no cross-sectional dependence among the countries of the panel". 
Pesaran (2004) developed the scaled LM $\left(L M_{S}\right)$ test, which provides more effective results than the LM test in cases where the number of cross sections $(N)$ is very large. For this test, the LM test statistic is obtained with Equation (10):

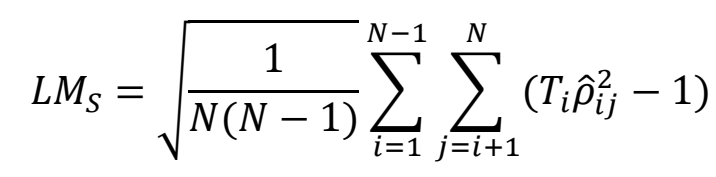

Pesaran (2004) also solved the size distortion problem of the $L M$ test, and developed the $C D$ test statistic to use when the time size is bigger than or equal to the cross-section size ( $T \geq$ $N)$. This operation can be done with Equation (11):

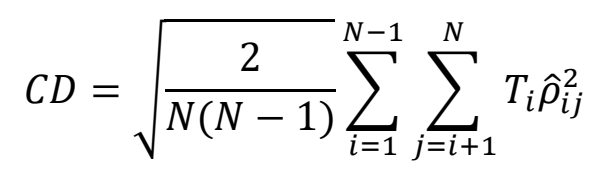

Baltagi, Feng and Kao (2012) obtained the $L M_{B C}$ (Bias Corrected LM) test statistic by adjusting the asymptotic deviations in the LM test. This operation can be done with Equation (12):

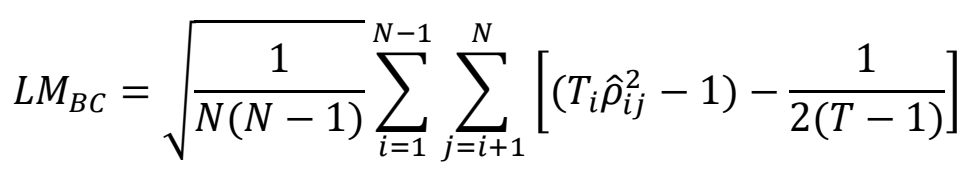

the null hypotheses of the $L M_{S}, C D$ and $L M_{B C}$ tests are also the same as the null hypothesis of the $L M$ test.

\subsubsection{Panel Unit Root Tests}

In this study, the stationarities of the series; and therefore, the existence of convergence among the countries were analyzed with Pesaran (2007) CADF panel unit root test and Hadri and Kurozumi (2012) panel unit root test. Additionally, first generation panel unit root tests like Maddala and Wu (1999) Fisher ADF and Fisher PP, Levin, Lin and Chu (2002) LLC and Im, Pesaran and Shin (2003) IPS were used to robustness check of the analyzes made with the second-generation panel unit root tests. The methods used for this purpose are explained below.

\subsubsection{CADF Unit Root Test}

Cross-Sectional Augmented Dickey Fuller (CADF) panel unit root test developed by Pesaran (2007) is the panel data analysis version of the ADF test for time series analysis that operates under cross sectional dependence. CADF test uses Equation (13) to examine the stationarity of a $Y_{i t}$ series:

$$
\Delta Y_{i t}=\rho_{i} Y_{i t-1}+u_{i t}
$$


The CADF test also allows the unit root parameter (here as $\rho_{i}$ ) to heterogenous among the cross sections that constitute the panel. In this method, it is assumed that the error term $\left(u_{i t}\right)$ in Equation (13) consists of two parts, namely the common factor for all series $\left(f_{t}\right)$ and the residuals specific to each series $\left(\varepsilon_{i t}\right)$.

$$
u_{i t}=\lambda_{i} f_{t}+\varepsilon_{i t}
$$

If the expression in Equation 14 is written on its place in Equation 13 and the necessary arrangements are made, it will be equal to:

$$
\Delta Y_{i t}=\alpha_{i}+\rho_{i} Y_{i t-1}+\lambda_{i} f_{t}+\varepsilon_{i t}
$$

as seen. Here, $f_{t}$; refers to non-observable common factors, and the dependence between crosssections is included in the analysis over this variable. CADF test can calculate individual unit root parameters for each cross section after calculating $\left(\tau_{i}\right)$, and the unit root test statistics (CIPS) valid for the panel can be calculated with Equation (16):

$$
\operatorname{CIPS}(N, T)=\bar{\tau}=\frac{1}{N} \sum_{i=1}^{N} \tau_{i}(N, T)
$$

Here, $N$; is the cross-sectional dimension of the study (number of countries), and $T$; is the time dimension. The null hypothesis of CADF and CIPS tests is; "Serie has a unit root". The critical values required to test these hypotheses were provided by Pesaran (2007, pp. 279-281).

\subsubsection{HK Unit Root Test}

The CADF and CIPS tests were also supported by the HK panel unit root test developed by Hadri and Kurozumi (2012), which considers autocorrelation and cross-sectional dependence for the series. The panel unit root test developed by Hadri and Kurozumi (2012) also allows the existence of common factors in the series. It can also report stationarity for some of the cross- sections. In this test, two different test statistics are produced:

$$
\begin{aligned}
& Z_{A}^{S P C}=\frac{1}{\hat{\sigma}_{i S P C}^{2} T^{2}} \sum_{t=1}^{T}\left(S_{i t}^{w}\right)^{2} \\
& Z_{A}^{L A}=\frac{1}{\tilde{\sigma}_{i L A}^{2} T^{2}} \sum_{t=1}^{T}\left(S_{i t}^{w}\right)^{2}
\end{aligned}
$$

Here SPC shows the statistic produced by Sul, Phillips, and Choi (2005), and LA shows the Lag-Augmented model. The hypotheses of this test are the opposite of the CADF test, and in this respect, $\mathrm{CADF}$ and $\mathrm{HK}$ are checking each other. The null hypothesis of HK panel unit root 
test is; "Serie is stationary". The critical values required to test these hypotheses are provided by Hadri and Kurozumi (2012, pp. 33).

\subsubsection{Fisher ADF Unit Root Test}

In this method, which was developed by the efforts of Maddala and Wu (1999), probability values of individual unit root tests that are obtained from ADF unit root test in time series that are applied to each cross section, are aggregated with the Fisher (1932) approach. This aggregation is done as follows, where $P_{i}$ is the probability values of the individual unit root tests of the cross sections:

$$
\operatorname{Prob}_{\text {Panel }}=-2 \sum_{i=1}^{N} \log \left(P_{i}\right)
$$

The obtained probability value is suitable for the chi-square distribution. The null hypothesis of this test is; "Serie has a unit root".

\subsubsection{Fisher PP Unit Root Test}

In this method, which was also developed by the efforts of Maddala and Wu (1999), probability values of individual unit root tests that are obtained from PP (Phillips - Perron) unit root test in time series that are applied to each cross section, are aggregated with the Fisher (1932) approach. This aggregation is done as follows, where $P_{i}$ is the probability values of the individual unit root tests of the cross sections:

$$
\operatorname{Prob}_{\text {Panel }}=-2 \sum_{i=1}^{N} \log \left(P_{i}\right)
$$

The obtained probability value is suitable for the chi-square distribution. The null hypothesis of this test is; "Serie has a unit root".

\subsubsection{LLC Unit Root Test}

Developed by Levin, Lin, and Chu (2002), this panel unit root test is based on the assumption that the unit root parameter $(\rho)$ is homogeneous among the cross sections forming the panel. In the LLC test, which is based on the systematics of the ADF unit root test in the time series analysis, it is assumed that the cross-section number $(N)$ and the time dimension (T) go to infinity, but $T$ increases faster, i.e. it is $N / T \rightarrow 0$ (Baltagi, 2005). The null hypothesis of this test is; "Serie has a unit root". The tau $(t)$ test statistic that is required to test these hypotheses in the LLC test: 


$$
\Delta X_{i t}=\rho X_{i t-1}+\sum_{j=1}^{m} \Delta X_{i t-j}+\gamma Z_{i t}+e_{i t}
$$

can be calculated by using the following equation:

$$
t_{\alpha}^{*}=\frac{t_{\alpha}-(N T) S_{N} \hat{\sigma}^{2} s e(\hat{\alpha}) \mu_{m T}^{*}}{\sigma_{m T}^{*}}
$$

Where; $\Delta \tilde{x}_{i t}=\alpha \tilde{x}_{i t-1}+\eta_{i t}$, and $t_{\alpha}$; refers to the standard $t$ statistic, $\hat{\alpha}=0, \hat{\sigma}^{2}$; refers to the estimated variance for error term $\eta_{i t}$, and $s e(\hat{\alpha})$; refers to the standard error of $\hat{\alpha}$.

\subsubsection{IPS Unit Root Test}

In the IPS panel unit root test developed by Im, Pesaran and Shin (2003), the unit root parameter $\left(\rho_{i}\right)$ is allowed to be heterogeneous among the cross sections that make up the panel. The null hypothesis of this test is; "Serie has a unit root". In the IPS test, the ADF unit root test is applied for each cross section, and the test statistics of the panel is obtained by taking the arithmetic mean of the obtained results.

$$
\bar{t}_{N T}=\frac{1}{N}\left(\sum_{i=1}^{N} t_{i T_{i}}\left(p_{i}\right)\right)
$$

Where, the standardized IPS statistic is obtained as follows:

$$
W_{\bar{t}_{N T}}=\frac{\sqrt{N}\left(\bar{t}_{N T}-\frac{1}{N} \sum_{i=1}^{N} E\left(\bar{t}_{N T}\left(p_{i}\right)\right)\right)}{\sqrt{\frac{1}{N} \sum_{i=1}^{N} \operatorname{Var}\left(\bar{t}_{N T}\left(p_{i}\right)\right)}}
$$

Where $E\left(\bar{t}_{N T}\left(p_{i}\right)\right.$ and $\operatorname{Var}\left(\bar{t}_{N T}\left(p_{i}\right)\right.$ show the expected value and variance of the $t$ statistics obtained from the ADF regressions, respectively.

\subsection{Results}

In this study, the existence of cross-sectional dependence among the countries included in the analysis is tested and the results are presented in Table 2.

Table 2: Results of Cross-Sectional Dependence Tests

\begin{tabular}{lcc}
\hline Test Method & Statistic & Prob. \\
\hline Breusch-Pagan LM & $3353.26^{\mathrm{a}}$ & 0.00 \\
Pesaran scaled LM & $75.70^{\mathrm{a}}$ & 0.00 \\
Bias-corrected scaled LM & $74.75^{\mathrm{a}}$ & 0.00 \\
Pesaran CD & $-1.75^{\mathrm{c}}$ & 0.07 \\
\hline
\end{tabular}

Note: $\mathrm{a}$ and $\mathrm{c}$ show that there is a cross-sectional dependence at the level of $1 \%$ and $10 \%$.

According to the results in Table 2, there is a cross-sectional dependence among the countries included in the panel. For this reason, it was considered a necessity to use the second- 
generation panel data analysis methods that take this situation into consideration for the next stages of the study.

The results of the CIPS statistics were obtained through separate CADF tests respectively for all countries, EU28, EU15, EU13 countries, and EU candidate countries. In addition, HK panel unit root test was also performed, and the results were presented in Table 3.

Table 3: The Convergence Test Results of Each Country Group to Its Group Average

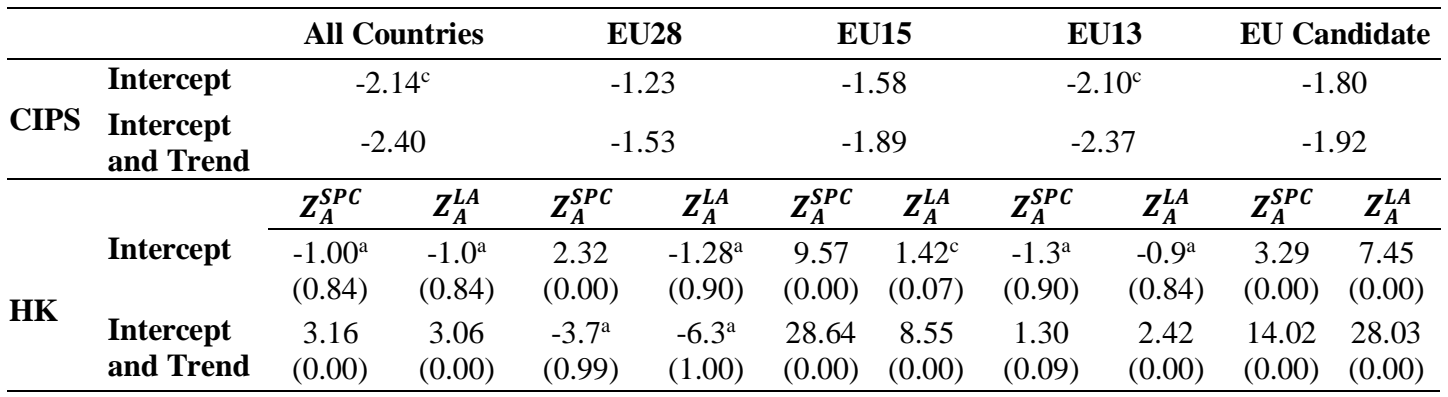

Note: While the critical values for 1\%, 5\% and 10\% significance level in Pesaran (2007: 280) (intercept only) are $-2.32,-2.15$ and -2.07 , respectively; critical values for $1 \%, 5 \%$ and $10 \%$ significance level in Pesaran (2007: 281) (intercept and trend) are $-2.88,-2.67$ and -2.58 , respectively. a and $\mathrm{c}$ show that the series are stationary at $1 \%$ and $10 \%$ significance level.

According to the CIPS test (CIPS statistics) results in Table 3; it can be stated that all countries group and the EU13 countries have a tendency for convergence, but this is a low-level convergence tendency. Because the related series are stationary only for the $10 \%$ significance level. According to HK test results, it can be stated that there is a convergence towards their group averages among the EU28 countries, among the EU15 countries and among the EU13 countries, and in the group of all countries consisting of EU member and candidate countries, and it can be stated that the weakest form of this convergence is valid for EU15 countries (as it is stationary at $10 \%$ significance level). However, according to the HK test, there is no foreign trade convergence among EU candidate countries. If the findings of the CADF and HK tests are assessed together, more convergence was determined as a result of the HK test. In both test methods, less convergence was detected in the intercept and trend models; it is considered that the reason for this situation is that the series are obtained by subtracting the average and they thus become trendless series. In short, according to the results in Table 3, there is foreign trade convergence in country groups other than EU candidate countries. The convergence of country groups to the average of the EU15's foreign trade balance was tested. Table 4 shows the test results. 
The Existence of Foreign Trade Balance Convergence In Eu Member and Candidate Countries: An Empirical Analysis

Table 4: The Test Results of Convergence of Countries to EU15 Average

\begin{tabular}{|c|c|c|c|c|c|c|c|c|c|}
\hline & & All C & tries & & & & & EU C & lidate \\
\hline & Intercept & & & & & & & & \\
\hline$C 1 P$ & $\begin{array}{l}\text { Intercept and } \\
\text { Trend }\end{array}$ & & & & & & & & \\
\hline & & $Z_{A}^{S P C}$ & $Z_{A}^{L A}$ & $Z_{A}^{S P C}$ & $Z_{A}^{L A}$ & $Z_{A}^{S P C}$ & $Z_{A}^{L A}$ & $Z_{A}^{S P C}$ & $Z_{A}^{L A}$ \\
\hline & Intercept & $\begin{array}{l}-3.93^{\mathrm{a}} \\
(1.00)\end{array}$ & $\begin{array}{l}-3.97^{\mathrm{a}} \\
(1.00)\end{array}$ & $\begin{array}{l}-3.72^{\mathrm{a}} \\
(0.99)\end{array}$ & $\begin{array}{l}-4.13^{\mathrm{a}} \\
(1.00)\end{array}$ & $\begin{array}{l}-2.67^{\mathrm{a}} \\
(0.99)\end{array}$ & $\begin{array}{l}-3.11^{\mathrm{a}} \\
(0.99)\end{array}$ & $\begin{array}{l}-1.56^{\mathrm{a}} \\
(0.94)\end{array}$ & $\begin{array}{l}-0.76^{\mathrm{a}} \\
(0.77)\end{array}$ \\
\hline Ho & $\begin{array}{l}\text { Intercept and } \\
\text { Trend }\end{array}$ & $\begin{array}{l}-1.84^{\mathrm{a}} \\
(0.96)\end{array}$ & $\begin{array}{c}0.29^{\mathrm{a}} \\
(0.38)\end{array}$ & $\begin{array}{l}-2.34^{\mathrm{a}} \\
(0.99)\end{array}$ & $\begin{array}{l}-0.89^{\mathrm{a}} \\
(0.81)\end{array}$ & $\begin{array}{l}-1.81^{\mathrm{a}} \\
(0.96)\end{array}$ & $\begin{array}{l}-2.56^{\mathrm{a}} \\
(0.99)\end{array}$ & $\begin{array}{l}-0.14^{\mathrm{a}} \\
(0.55)\end{array}$ & $\begin{array}{c}3.60 \\
(0.00)\end{array}$ \\
\hline
\end{tabular}

According to the results of the CADF test (CIPS statistics) in Table 4, it was determined that the EU28 and EU13 countries converge towards the EU15 countries in terms of foreign trade balance. In this case, it can be stated that the harmonization program implemented by the EU has produced successful results. For the EU candidate countries, there is no convergence towards the EU15.

According to HK test results, all country groups converge to the average of EU15 in terms of foreign trade balance. This relationship was detected more robustly with the HK test. The convergence of EU candidate countries to the EU13's foreign trade balance average was also tested. Table 5 shows the test results.

Table 5: Existence Test of Convergence of EU Candidate Countries to EU13 Average

\begin{tabular}{llcc}
\hline & & \multicolumn{2}{c}{ AB Candidate } \\
\cline { 3 - 4 } CIPS & Intercept & \multicolumn{2}{c}{-1.72} \\
& Intercept and Trend & $Z_{A}^{S P C}$ & \multicolumn{2}{c}{$Z_{A}^{L A}$} \\
\hline \multirow{3}{*}{ HK } & Intercept & $-1.23^{\mathrm{a}}(0.89)$ & $0.12^{\mathrm{a}}(0.45)$ \\
\cline { 3 - 4 } & Intercept and Trend & $-0.38^{\mathrm{a}}(0.64)$ & $0.20^{\mathrm{a}}(0.42)$ \\
\hline
\end{tabular}

According to the results of the CADF test (CIPS statistics) in Table 5; in terms of foreign trade balance, it can be stated that the EU candidate countries, which were not able to converge to the EU15 countries according to the results of the CADF test in Table 4, was not able to converge to the EU13 countries as well.

According to the HK test results, it was determined that the foreign trade balance of the 8 EU candidate countries converged to the foreign trade balance of the 13 countries that became members of the EU later. 


\subsection{Robustness Check}

In order to check the reliability of the results of CADF and HK tests of this study, first generation panel unit root tests were used. For this purpose, Fisher ADF, Fisher PP, LLC and IPS unit root tests were used. Table 6 shows the test results.

Table 6: The Convergence Test Results of Each Country Group to Its Group Average

\begin{tabular}{lcccccc}
\hline & & All Countries & AB28 & AB15 & AB13 & AB Candidate \\
\cline { 3 - 7 } Fisher & Intercept & $93.26^{\mathrm{b}}(0.04)$ & $67.98(0.13)$ & $36.93(0.17)$ & $42.95^{\mathrm{b}}(0.01)$ & $21.73(0.15)$ \\
ADF & Intercept and Trend & $78.68(0.27)$ & $61.07(0.29)$ & $-0.20(0.42)$ & $\left.40.79^{\mathrm{b}} 0.03\right)$ & $12.69(0.69)$ \\
\hline Fisher & Intercept & $81.41(20)$ & $58.64(0.37)$ & $39.52(0.00)$ & $46.13^{\mathrm{a}}(0.00)$ & $24.00^{\mathrm{c}}(0.08)$ \\
PP & Intercept and Trend & $73.22(0.43)$ & $49.27(0.72)$ & $-0.03(0.48)$ & $38.45^{\mathrm{c}}(0.05)$ & $22.60(0.12)$ \\
\hline \multirow{2}{*}{ LLC } & Intercept & $-3.60^{\mathrm{a}}(0.00)$ & $-3.29^{\mathrm{a}}(0.00)$ & $-2.48^{\mathrm{a}}(0.00)$ & $-1.84^{\mathrm{b}}(0.03$ & $-0.82(0.20)$ \\
& Intercept and Trend & $-1.73^{\mathrm{b}}(0.04)$ & $-1.18(0.11)$ & $29.01(0.51)$ & $-1.43^{\mathrm{c}}(0.07)$ & $0.13(0.55)$ \\
\hline \multirow{2}{*}{ IPS } & Intercept & $-2.22^{\mathrm{b}}(0.01)$ & $-1.66^{\mathrm{b}}(0.04)$ & $-1.22(0.11)$ & $-2.49^{\mathrm{b}}(0.00)$ & $-1.34^{\mathrm{c}}(0.08)$ \\
& Intercept and Trend & $-1.10(0.13)$ & $-1.06(0.14)$ & $33.16(0.31)$ & $-1.95^{\mathrm{b}}(0.02)$ & $0.25(0.60)$ \\
\hline
\end{tabular}

Note: Prob values in parentheses. ${ }^{\mathrm{a}} ; \mathrm{p}<0.01,{ }^{\mathrm{c}} ; \mathrm{p}<0.10$

The results in Table 6 are in more conformity with the HK test rather than the CADF test, and show that all country groups converge to their group average at the point of foreign trade balance. The convergence of the country groups to the average of the EU15's foreign trade balance was tested and the obtained results were presented in Table 7.

Table 7: The Convergence Test Results of the Country Groups to the Average of the EU15's Foreign Trade Balance

\begin{tabular}{lccccc}
\hline & & All Countries & AB28 & AB13 & AB Candidate \\
\cline { 3 - 6 } Fisher & Intercept & $75.16(0.37)$ & $55.44(0.49)$ & $18.50(0.85)$ & $19.72(0.23)$ \\
ADF & Intercept and Trend & $69.15(0.57)$ & $48.80(0.74)$ & $19.79(0.80)$ & $20.34(0.20)$ \\
\hline \multirow{2}{*}{ Fisher } & Intercept & $83.84(0.16)$ & $59.47(0.35)$ & $19.94(0.79)$ & $24.36^{\mathrm{c}}(0.08)$ \\
PP & Intercept and Trend & $78.44(0.28)$ & $54.75(0.52)$ & $21.59(0.71)$ & $23.68^{\mathrm{c}}(0.09)$ \\
\hline \multirow{2}{*}{ LLC } & Intercept & $-3.66^{\mathrm{a}}(0.00)$ & $-3.42^{\mathrm{a}}(0.00)$ & $-2.37^{\mathrm{a}}(0.00)$ & $-1.37^{\mathrm{c}}(0.08)$ \\
& Intercept and Trend & $-0.58(0.27)$ & $0.56(0.71)$ & $1.06(0.85)$ & $-2.29^{\mathrm{b}}(0.01)$ \\
\hline \multirow{2}{*}{ IPS } & Intercept & $-1.26(0.10)$ & $-0.87(0.19)$ & $0.03(0.51)$ & $-1.04(0.14)$ \\
& Intercept and Trend & $-0.03(0.48)$ & $0.44(0.67)$ & $0.67(0.75)$ & $-0.89(0.18)$ \\
\hline
\end{tabular}

Not: Prob values in parentheses. ${ }^{\mathrm{a}} ; \mathrm{p}<0.01,{ }^{\mathbf{c}} ; \mathrm{p}<0.10$

The results of the Fisher ADF and Fisher PP tests in Table 7 are compatible with the findings of the CADF test, and the results of the LLC and IPS tests are compatible with the findings of the HK test, and according to the LLC and IPS tests, it can be stated that all country groups converge to the average of the EU15 in terms of the foreign trade balance. The convergence of the EU candidate countries to the average of the EU13's foreign trade balance was tested and the achieved results were presented in Table 8.

Table 8: The Convergence Test Results of the EU Candidate Countries to the Average of the EU13's Foreign Trade Balance 
The Existence of Foreign Trade Balance Convergence In Eu Member and Candidate Countries: An Empirical Analysis

\begin{tabular}{lcc}
\multirow{2}{*}{ Fisher ADF } & Intercept & $23.65^{\mathrm{c}}(0.09)$ \\
& Intercept and Trend & $17.55(0.35)$ \\
\hline \multirow{2}{*}{ Fisher PP } & Intercept & $22.67(0.12)$ \\
& Intercept and Trend & $26.29^{\mathrm{c}}(0.05)$ \\
\hline \multirow{2}{*}{ LLC } & Intercept & $-1.49^{\mathrm{c}}(0.06)$ \\
\multirow{2}{*}{ IPS } & Intercept and Trend & $-1.49^{\mathrm{c}}(0.06)$ \\
\hline
\end{tabular}

Not: Prob values in parentheses. ${ }^{\mathrm{c}} ; \mathrm{p}<0.10$

According to the results in Table 8, it can be said that the EU candidate countries converge weakly (at the level of 10\%) to EU13 countries in terms of the foreign trade balance. These results are more in conformity with the findings of the HK test rather than the CADF test. Therefore, the determinations made in this study are robust (consistent, resilient).

\section{CONCLUSIONS AND POLICY IMPLICATIONS}

Trade balance deficit is an important problematic area for all countries, and it is the main cause of the current account deficit and the economic crises as a result of it, too. It is useful to frequently analyze the level of these deficits. The European Union directs and supports both its Member States and candidate countries in order to reduce their current account deficits and trade balance deficits. There are EU funds allocated for a solution, and grants are provided to countries through these funds, provided that they implement the proposed programs.

In this study, the existence of convergence between the EU member and EU candidate countries in terms of the foreign trade balance was analyzed with second-generation panel data analysis methods operating under cross-sectional dependence, by using data from the 20002019 period. In the study, tests on the existence of cross-sectional dependence among the countries included in the analysis and it was detected that there was cross-sectional dependence among the countries included in the panel. For this reason, it was considered a necessity to use the second-generation panel data analysis methods that take this situation into consideration for the next stages of the study.

Therefore, CADF and HK panel unit root tests were carried out in order to test the existence of each country group's convergence to their group average. Except for EU candidate countries, i.e., in the 36-country panel, in the EU28, EU15, and EU13 countries, it was determined that there was a convergence towards their own group averages in terms of the foreign trade balance.

Then, the convergence of the countries to the group average of the EU15 was tested by CADF and HK methods; and it was determined that the 36-country panel, the EU28, EU13 
countries and the EU candidate countries tend to converge towards the foreign trade balance of the EU15.

Finally, the convergence of EU candidate countries to the EU13's foreign trade balance average was tested by CADF and HK methods, and according to the CADF tests, the EU candidate countries that were unable to converge to the EU15 countries were also not able to converge to the EU13 countries. However, according to the HK test results, it was determined that the foreign trade balance of the $8 \mathrm{EU}$ candidate countries converged to the foreign trade balance of the 13 countries that became members of the EU later.

In order to test the consistency of the results that were obtained with the secondgeneration panel unit root tests, the first-generation panel unit root tests of Fisher ADF, Fisher PP, LLC and the IPS panel unit root tests were used. These tests revealed that the results obtained with the second-generation panel unit root tests were robust.

Based on the findings of this study; it can be stated that the EU harmonization programs were able to be implemented effectively, and that 13 countries that joined the EU later and 8 countries that are negotiating to join the EU tend to converge to the EU15 in terms of foreign trade balance, and that this is an achievement for the EU. It shouldn't forget that countries such as Greece, Luxembourg, and Portugal, which are among the EU15 members, have a significant foreign trade deficit, and the debt crises that these countries are bringing some burdens to the EU. At such a point, both EU13 countries and EU candidate countries should try not to create new burdens on EU. At this point, if necessary, it may be beneficial to set certain threshold values for the states, as in the 1993 Maastricht Criteria, to deprive countries that do not meet these criteria from EU funds, to suspend their EU membership, and to declare that new countries will not be participated to the EU membership without meeting these criteria.

\section{REFERENCES}

ARESTIS, P., CHORTAREAS, G., MAGKONIS, G. and MOSCHOS, D. (2014). Inflation Convergence and Inflation Targeting: International Evidence, Journal of International Financial Markets, Institutions and Money, Vol: 31, s. 285-295.

ATALAY, S.S. (2007). Real Convergence in the New EU Countries and Turkey. Central Bank of Turkey Republic, Specialization Qualification Thesis, Ankara.

ATO (2003). 30 Industries have a Chinese Invasion, https://www.hurriyet.com.tr/ekonomi/30sektorde-cin-istilasi-var-191036, Access Date: 01.04.2021. 
BALTAGI, B.H. (2005). Econometric Analysis of Panel Data, (Third Edition), John Wiley \& Sons Gmbh, West Sussex, England.

BALTAGI, B.H. and PESARAN, M.H. (2007). Heterogeneity and Cross Section Dependence in Panel Data Models: Theory and Applications, Journal of Applied Econometrics, Vol: 22, s.229-232.

BALTAGI, B. H, FENG, Q. and KAO C. (2012). A Lagrange Multiplier test for Cross-sectional Dependence in a Fixed Effects Panel Data Model, Journal of the Econometrics, Vol: 170, s.164-177.

BARRO, R.J. and SALA-I-MARTIN, X. (1990). Economic Growth and Convergence Across the United States, NBER Working Papers, No. 3419.

BAUMOL, W.J. (1986). Productivity Growth, Convergence and Welfare: What the Long-Run Data Show? The American Economic Review, Vo: 76(5), s.1072 - 1085.

BREUSCH, T. S. and PAGAN, A.R. (1980). The Lagrange Multiplier Test and Its Applications to Model Specification Tests in Econometrics, Review of Economic Studies, Vol: 47, s.239-53.

BURKETT, P. and HART-LANDSBERG, M. (2003). A Critique of "Catch-Up" Theories of Development, Journal of Contemporary Asia, Vol: 33(2), s.147-171.

DORNBUSCH, R. and FISCHER, F. (1990). Macroeconomics, McGraw-Hill, International Editions.

DURLAUF, S.N. and JOHNSON, P.A. (1995). Multiple Regimes and Cross-Country Growth Behavior, Journal of Applied Econometrics, Vol: 10(4), s.365-384.

EUROPEAN COMMISSION (2015). European Structural and Investment Funds 2014-2020: Official Texts and Commentaries, https://ec.europa.eu/regional_ policy/sources/docgener/guides/blue_book/blueguide_en.pdf, Access Date: 19.03.2021.

EUROPEAN COMMISSION (2021). Convergence Criteria for Joining, https://ec.europa.eu/info/business-economy-euro/euro-area/enlargement-euroarea/convergence-criteria-joining_en, Access Date: 19.03.2021.

FREUND, C. L. (2000). Current Account Adjustment in Industrialized Countries, Board of Governors of the FED International Finance, Discussion Papers, No. 692. 
GALOR, O. (1996). Convergence? Inference from Theoretical Models, Economic Journal, Vol: 206, s. $1056-1069$.

GENCOGLU, P., KUSKAYA, S. and BUYUKNALBANT, T. (2020). Evaluation of Sustainability of Health Expenditures in The Selected OECD Countries with Panel Unit Root Tests, Ankara University SBF Journal, Vol: 75(4), s.1283-1297.

GOGUL, P.K. and KORAP, L. (2014). New Evidence Upon Testing the Issue of Economic Convergence: OECD Evidence, Kastamonu University Journal of Faculty of Economics and Administrative Sciences, Vol: 4, s.60-73.

HADRI, K., and KUROZUMI, E. (2012). A Simple Panel Stationarity Test in The Presence of Serial Correlation and A Common Factor, Economics Letters, Vol: 115(1), s. 31-34.

HAWKINS, J. and TURNER, P. (2008). Managing Foreign Debt and Liquidity Risks in Emerging Economies: An Overview, https://www.bis.org/publ/plcy08a.pdf, Access Date: 19.03.2021.

IMF (2020). Direction of Trade Statistics (DOTS), https://data.imf.org/?sk=9D6028D4-F14A464C-A2F2-59B2CD424B85, Access Date: 16.03.2021.

IM, K. S., PESARAN, M. H. and SHIN, Y. (2003). Testing for Unit Roots in Heterogeneous Panels, Journal of Econometrics, Vol: 115, s.53-74.

LABONTE, M. (2010). Is the U.S. Current Account Deficit Sustainable? Congressional Research Service, No. 7-5700.

LEVIN, A., LIN, C. F. and CHU, C. (2002). Unit Root Tests in Panel Data: Asymptotic and Finite-Sample Properties, Journal of Econometrics, Vol. 108, s.1-24.

LOPEZ, C. and PAPELL, D. H. (2012). Convergence of Euro Area Inflation Rates, Journal of International Money and Finance, Vol: 31(6), s.1440-1458.

LUCAS, R.E. (2000). Some Macroeconomics for the 21st Century, Journal of Economic Perspectives, Vol: 14(1), s.159-168.

MADDALA, G. S. and WU, S. (1999). A Comparative Study of Unit Root Tests with Panel Data and a New Simple Test, Oxford Bulletin of Economics and Statistics, Vol: 61, s.631-652. 
The Existence of Foreign Trade Balance Convergence In Eu Member and Candidate Countries: An Empirical Analysis

OZDAMAR, G. (2015). Factors Affecting Current Account Balance of Turkey: A Survey with The Cointegrating Regression Analysis, Journal of Business, Economics \& Finance, Vol: 4(4), s.633-658.

PESARAN, M. H. (2004). General Diagnostic Tests for Cross Section Dependence in Panels, Cambridge Working Papers in Economics, No. 435.

PESARAN, M.H. (2007). A Simple Panel Unit Root Test in The Presence of Cross-Section Dependence, Journal of Applied Econometrics, Vol: 22, s.265-312.

ROWTHORN, R. and RAMASWAMY, R. (1997). Deindustrialization: Causes and Impacts, IMF Working Paper, No. WP/97/42.

SAMUE, A. (2019). International Trade and Its Impact on the Global Economy, Kenyatta University.

SARACOGLU, B. and DOGAN, N. (2005). "Convergence Analysis of European Union Countries and European Union Candidate Countries", 7th National Econometrics and Statistics Symposium, 26-27 May, Istanbul.

SOLOW, R.M. (1956). A Contribution to the Theory of Economic Growth, The Quarterly Journal of Economics, Vol: 70(1), s.65-94.

STRAZICICH, M. C., LEE, J. and DAY, E. (2004). Are Incomes Converging Among OECD Countries? Time Series Evidence with Two Structural Breaks, Journal of Macroeconomics, Vol: 26(1), s.131-145.

SUL, D., PHILLIPS, P.C.B. and CHOI, C.Y. (2005). Prewhitening Bias in HAC Estimation, Oxford Bulletin of Economics and Statistics, Vol: 67, s.517-546.

SWAN, T.W. (1956). Economic Growth and Capital Accumulation, Economic Record, Vol: 32, s.334-361.

VARBLANE, U. and VAHTER, P. (2005). An Analysis of The Economic Convergence Process in The Transition Countries, Tartu University Press, No. 241.

WORLD BANK (2020a). Merchandise Exports (Current US\$), https://data.worldbank.org/indicator/TX.VAL.MRCH.CD.WT?view=chart, Access Date: 16.03.2021. 
WORLD BANK (2020b). Merchandise Imports (Current US\$), https://data.worldbank.org/indicator/TM.VAL.MRCH.CD.WT?view=chart, Access Date: 16.03.2021.

WORLD BANK (2021c). New World Bank Country Classifications by Income Level: 20202021. https://blogs.worldbank.org/opendata/new-world-bank-country-classificationsincome-level-2020-2021, Access Date: 16.03.2021.

WORLD BANK (2021d). GDP per capita (current US\$). https://data.worldbank.org/indicator/NY.GDP.PCAP.CD?view=chart, Access Date: 16.03.2021.

WORLD BANK (2021e). GDP (current US\$). https://data.worldbank.org/indicator/ NY.GDP.PCAP.CD?view=chart, Access Date: 16.03.2021.

YILANCI, V. and ERIS, Z.A. (2013). Purchasing Power Parity in African Countries: Further Evidence from Fourier Unit Root Tests Based on Linear and Nonlinear Models, South African Journal of Economics, Vol: 81(1), s.20-34. 